\title{
Growth response of Scots pine to changing climatic conditions over the last 100 years: a case study from Western Hungary
}

\author{
Dávid Misi ${ }^{1} \cdot$ Katalin Náfrádi ${ }^{1}$
}

Received: 3 June 2016 / Accepted: 23 December 2016 / Published online: 25 January 2017

(C) Springer-Verlag Berlin Heidelberg 2017

\begin{abstract}
Key Message Climate change has a significant influence on the climate-growth relationship of Scots pine in Western Hungary, and this typically expressed as a decrease in the strength of the connection between treering width variation and climate data.

Abstract This paper aims to expand our understanding of the climate-growth relationship of Scots pines in Transdanubia. Changes in the influence of climate on tree growth over various time-scales have been the subject of numerous investigations with pine trees, but these relationships have never been explored for Scots pines in Hungary. In this research, Pearson correlation values in 25-year moving windows were used to evaluate the temporal relationships of temperature, precipitation and tree-ring width variation, and additionally to investigate how these might be connected to climate change between 1915 and 2014 . In the cases of summer precipitation and late winter-early spring temperature, our results detected a significant positive influence on the tree-ring width development of those Scots pines at our study sites. Furthermore, intensive warming over the last 100 years has resulted in a changing relationship between tree-ring width variation and climate data. In this study, the temporal instability of the climategrowth relationship was observed in every important month of tree-ring growth, and the response of growth to climate declined sharply in most of the studied periods. This indicates that ongoing climate change has already altered the
\end{abstract}

Communicated by S. Leavitt.

Dávid Misi

misid@geo.u-szeged.hu

1 Department of Geology and Paleontology, University of Szeged, Egyetem utca 2-6, Szeged 6722, Hungary climate-growth relationship in Scots pines in certain sites of Western Hungary.

Keywords Dendroclimatology - Climate change . Climate-growth relationship $\cdot$ Moving window correlation

\section{Introduction}

Climate change, together with its side effects, has significant influence on forest ecosystems. For example, warming can modify the onset of the growing season (Koprowski 2013), its extension (Menzel and Fabian 1999) and the dynamics of tree-ring formation during the active period (D'Arrigo et al. 2008; de Luis et al. 2014). Increasing temperature has already caused measurable changes in the larger region in which our sample sites are located. In Slovenia, de Luis et al. (2014) reported a warming trend and noted that the long-term increase in spring temperatures limits growth in most tree species, thereby having a negative impact on forest productivity. Investigating spruce and larch, Koprowski $(2012,2013)$ also found a significant degree of influence thanks to changing climatic conditions in Poland, noting that rising temperatures in February and March can decrease tree resistance to low temperatures, making them more vulnerable to late winter-early spring frosts. In contrast, Churkova et al. (2014) in their study of spruce found that a rise in temperature in spring has a positive effect on tree-ring formation in the Swiss Alps at high altitudes.

As Scots pine is among the most frequently used species for dendrochronological analysis, its climate-growth relationship has been investigated numerous times under different climatic, environmental and altitudinal conditions (Sánchez-Salguero et al. 2015; Bauwe et al. 2015; Bauwe 
et al 2013; Panayotov et al. 2013; Bogino et al. 2009; Pärn 2009; Eilmann et al. 2006). In relation to current climate trends, different recent and future responses have been reported and estimated. Although the capacity of Scots pine to adapt to variable climatic and environmental conditions is large, as a result of warming decreased growth trends are predicted for the species in central and southern Europe (Reich and Oleksyn 2008).

While climate change may have serious impacts in the Carpathian Basin (Parry et al. 2007; Bozó 2010), which may significantly influence the forest ecosystem, there have been few studies of the temporal alterations in the climate-growth relationship of certain tree species (e.g. on beech, Garamszegi and Kern 2014), and these are particularly lacking for pine trees (with the exception of Misi and Náfrádi 2016b). Of pine species in Hungary, Scots pine represents the largest group, and although it is not native, it plays an essential role in Hungarian forest composition (NFCSO Forestry Directorate Forest Inventory 2014). To evaluate the behavior of the tree-ring width variation of Scots pine, two well-known pine-covered sites from the western part of Hungary were selected for the study. The sites were selected with the aim of enabling the investigation of the Scots pine's climate growth relationship under similar climatic conditions but with different growth environments. While the sites are relatively close to each other, the current state of the two stands differs mainly in their divergent pedological conditions and water management regimes. The current research aims (1) to identify which climate parameters affect tree-ring width variation in our sites, and subsequently (2) to investigate how the influence of changing climatic conditions has evolved over the last 100 years and has modified the climate-growth relationship.

\section{Materials and methods}

\section{Study site and climate data}

One of our study site is Fenyófó (FFO, N47 $21^{\circ}$, E17 $47^{\circ}$, $250 \mathrm{~m}$ a.s.1.), situated in the northern part of Western Hungary on the northern slopes of the Bakony Mtns (Fig. 1a). This forest, which is the oldest pine stand in Hungary, is growing on secondarily evolved dune sand and weakly humic sandy soil formed from a calcareous sand bedrock (Borhidi 2003). Due to the thick sand layer and intensive summer evaporation, the groundwater level usually subsides below the roots, which promotes poor water management and unfavorable conditions for tree growth. The forest is mixed, with oak (Quercus cerris, Quercus robur, Quercus petraea), silver birch (Betula pendula) and ash (Fraxinus ornus), but the canopy is dominated by a pine population of uneven age.

The second site is Szalafó (SZFO, N46 ${ }^{\circ} 52^{\prime}, \mathrm{E} 16^{\circ} 21^{\prime}$, $270 \mathrm{~m}$ a.s.1.), and is situated in the western part of the country, near to the Austrian and Slovenian borders. The pedological conditions at this site are better; the dominant soil is brown forest soil formed on Quaternary sediments. The dominant species is Scots pine, but the forest is mixed, with oak, birch, ash, beech (Fagus sylvatica) and spruce (Picea abies).
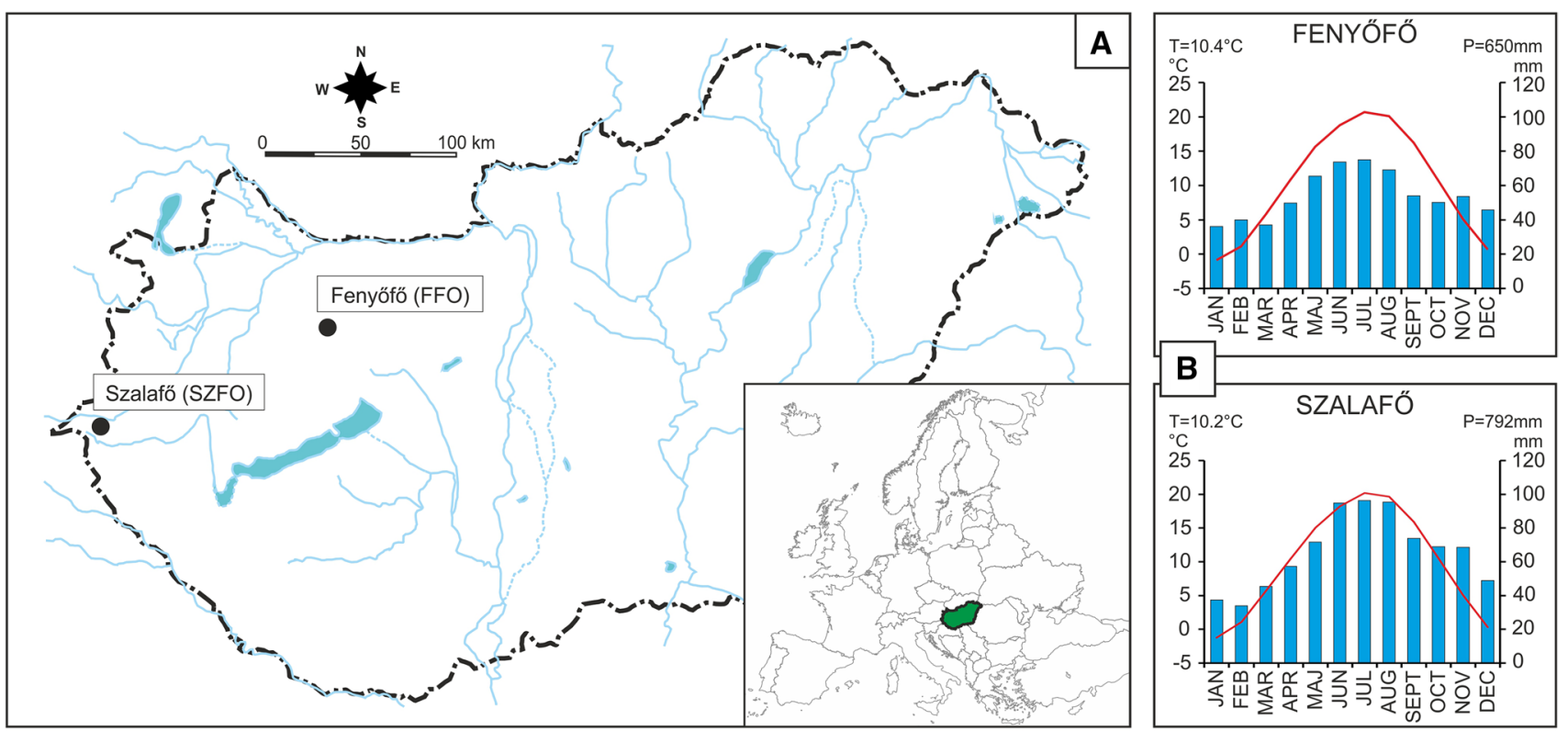

Fig. 1 Location of study sites (a) and long-term characteristics of temperature (lines) and precipitation (bars) (b) 
Both areas have their precipitation and temperature maxima in summer and similar annual distributions of temperature and precipitation values. Site SZFO has higher total precipitation $(\sim 800 \mathrm{~mm})$, with a maximum in July, but site FFO is warmer with its $10.4^{\circ} \mathrm{C}$ long-term annual mean temperature (Fig. 1b).

Since the closest meteorological stations do not have sufficiently long instrumental meteorological data for our research, we used CRU TS $3.230 .5^{\circ} \times 0.5^{\circ}$ (Harris and Jones 2015) gridded monthly and seasonal temperature and precipitation data for the period of 1915-2014. The dataset we needed was extracted for the sample areas using the KNMI Climate Explorer web page (http://climexp.knmi. $\mathrm{nl})$. To check the reliability of the gridded data, it was compared to the shorter-term instrumental data already provided by stations near the study sites; a high correlation for the overlapping periods was found.

\section{Climate over the last 100 years}

According to the temperature data of sites FFO and SZFO, a remarkable warming trend started at the beginning of the 1990s. With some exceptions, the temperature of the first 75 years of our study period fell below the mean of the 1971-2000 reference period (Fig. 2), especially in the winters between 1940 and 1964, which proved to be the coldest era of the last 100 years. After 1990, however, temperature exceeded the reference period's mean in every month at both study sites. The biggest changes occurred in April, in the summer months and in November. Winters were also significantly warmer. Between 1990 and 2014 the 25-year mean of the winter months did not drop below $0{ }^{\circ} \mathrm{C}$ (except in December in site FFO).

In monthly precipitation values only small fluctuations can be observed, but seasonally and annually there are
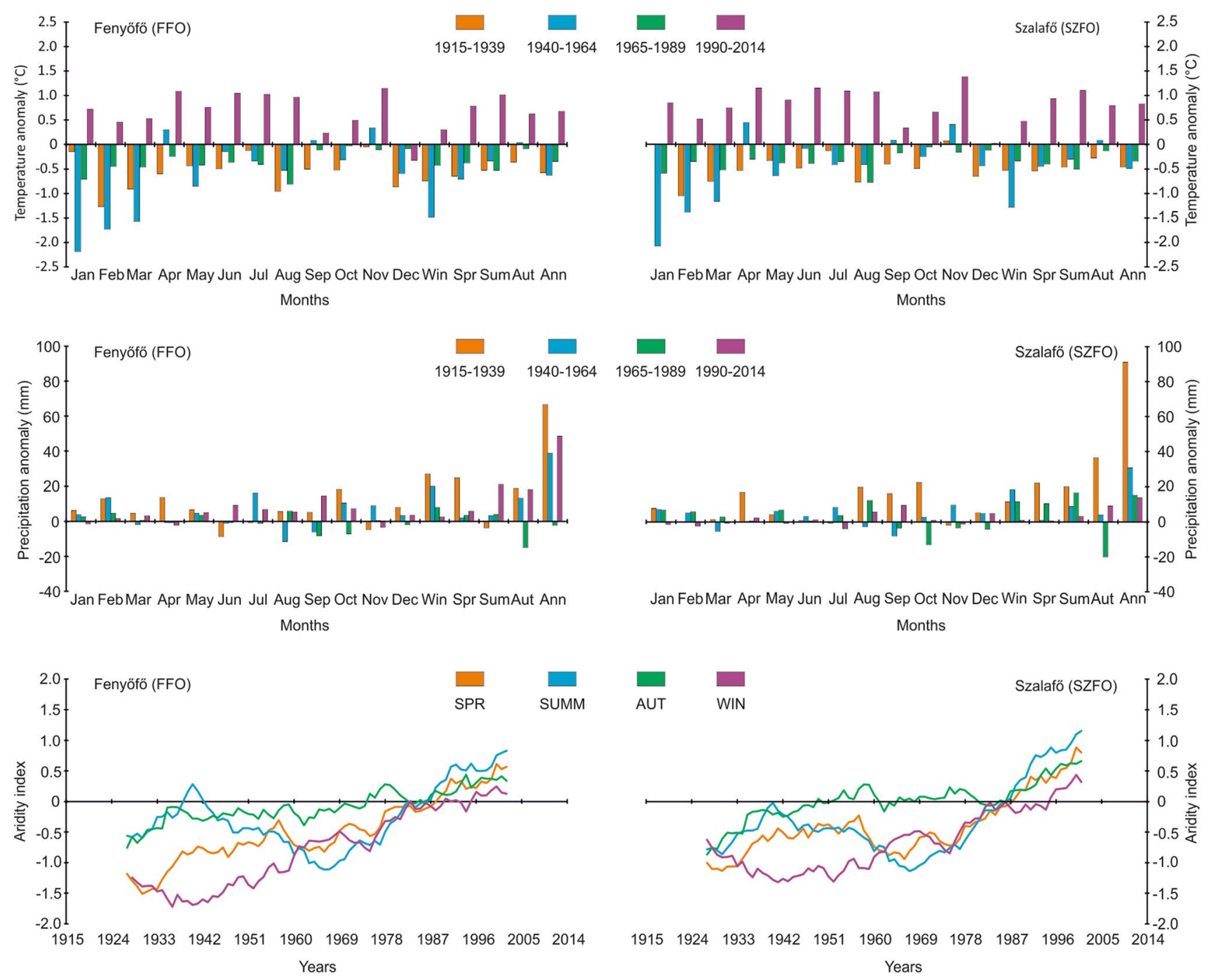

Fig. 2 Temperature and precipitation anomalies in the last 100 years with respect to the 1971-2000 reference period, together with the aridity index for each study site. Temporal changes in aridity were investigated using a 25 -year moving mean calculation for each season 
significant changes. Considering months individually, April and October at both sites, and August in the SZFO site experienced the greatest precipitation decreases (Fig. 2). In the trends of seasonal precipitation data, however, a different pattern is observed. While summer precipitation has been increasing since the beginning of the 1900s at the FFO site, at the SZFO site the opposite trend is observed, with a massive decrease taking place. The mean of the first 25-year period (1915-1939), $848 \mathrm{~mm}$, declined by almost $80 \mathrm{~mm}$ by the end of the last quarter of the study period (1990-2014: $770 \mathrm{~mm}$ ).

It seemed likely that the small decrease in precipitation and the dramatic increase in temperature would be combined in a steeply rising aridity index. As the 25 -year moving mean values of the aridity index over the last 100 years show, climatic conditions have rapidly changed at both sites (Fig. 2). Before 1990, aridity indices were typically below the 1971-2000 level in both spring and summer, and it is these seasons that are particularly important in tree ring growth. Because of the warming trend, every season's aridity index value had risen considerably above the reference period's mean by the end of our study period.

\section{Sampling and chronology building}

In the two sampling periods (in 2014 at site FFO; in 2015 at site SZFO), old, dominant, healthy trees were selected for sampling. In total, 53 individuals were cored at breast height, and two samples were taken at $180^{\circ}$ to each other in each tree. All of the samples were air-dried, then sanded and polished with 8 different sandpapers to enhance treering structure. The measurement of tree-ring width was performed using a LINTAB Measurement Station, at $0.01 \mathrm{~mm}$ precision, from the pith to the bark (Rinn 2003). Rings formed before 1915 were excluded, which marks the beginning of our study period. The on-screen crossdating of individual series was done using the TSAPX and TSAPWin programs. Series intercorrelation, missing ring identification and the detection of possible dating errors were checked using the COFECHA program (Holmes 1983).

\section{Climate signal}

Because of the trees' age, size and the effects of stand dynamics, several non-climatic trends are preserved in tree rings, and these need to be removed. All of the series were, therefore, standardized by fitting a cubic smoothing spline with a $50 \%$ frequency response at $67 \%$ of the length of the individual series (Cook and Peters 1981). Autocorrelation was removed from each individual index, then all the detrended residual series were averaged into a site chronology using the biweight robust mean (Cook 1985).
The stability of the common signal preserved in the index series was determined by calculating the Expressed Population Signal (EPS), which was applied with a 25-year window lagged by 1 year using the widely accepted threshold of 0.85 (Wigley et al. 1984). In addition, the mean interseries correlation (Rbar) was computed using the same window and lag as the EPS values. Standardization and index calculation procedures were carried out using the ARSTAN program (Cook and Krusic 2006).

To evaluate the connection between climate data and tree-ring indices, Pearson correlation coefficients were calculated from May of the previous year (MAY) to October of the current year (Oct) of tree-ring formation. Not only were individual months analyzed, but all seasonal and annual data as well. For the investigation of the effect of changing climatic conditions on tree-ring growth during the study period, 25-year moving window correlations of meteorological and tree-ring width data were computed. Only those months and periods were considered in which precipitation or temperature had significant or near-significant correspondence with tree-ring indices in the whole time-span of the study.

Not only were precipitation and temperature individually examined, but an aridity index (AI) was also calculated to highlight the influence of drought conditions on tree ringwidth variability. Calculations were carried out using precipitation and temperature anomalies according to the following formula

$\mathrm{AI}=\left(\left(T-T_{\mathrm{m}}\right) / T_{\mathrm{d}}\right)-\left(\left(P-P_{\mathrm{m}}\right) / P_{\mathrm{d}}\right)$

where $T$ is the temperature, $T_{\mathrm{m}}$ is the mean temperature of the reference period (1971-2000), $T_{\mathrm{d}}$ is the deviation of the reference period temperature, $P$ is the precipitation, $P_{\mathrm{m}}$ is the mean precipitation of the reference period, and $P_{\mathrm{d}}$ is the deviation of the reference period precipitation. The values of this index are positive in the case of drought events. Computation was made for every month of the current year of tree-ring formation, for all seasons and for annual data. AI values were tested against meteorological data using the Pearson correlation.

\section{Results}

\section{Tree-ring chronologies}

Two site chronologies were developed: one for the FFO site derived from the tree-ring widths of 19 trees, and another for the SZFO site comprising the data from 34 trees. The raw chronologies show a high level of similarity to each other, with a correlation of $r=0.66$. Only small differences are to be found in the most common statistical indicators, such as standard deviation, mean segment length, series 
intercorrelation and autocorrelation (Table 1). The site chronology for FFO starts with 5 trees in 1915 and reaches its replication maximum in 1982. Replication in the SZFO chronology begins with 10 cored trees at the beginning of the record and reaches its maximum in 1960.

\section{Climate-growth relationship}

Expressed population signal (EPS) values indicated a stable and strong common signal in both sites. Values are above the widely accepted 0.85 threshold, and exceed the currently recommended higher critical level (ca. 0.90) (Mérian et al. 2013) as well (Fig. 3e). Similarly to the case of EPS, mean interseries correlation (Rbar) also indicates strong relationships between the individual series, with averages of 0.43 (SZFO) and 0.44 (FFO). These results suggest that both chronologies carry a reliable climate signal and are suitable to represent the whole pine stand.

According to the results of a correlation analysis between tree-ring indices and climate data, growth at our sites has corresponded well to meteorological conditions. Considering the months individually, precipitation in June and July has the biggest positive impact on tree-ring width variation, but over a longer time-scale, the total precipitation of summer has the greatest effect (Fig. 4). The greatest influence of temperature is negative in August, but the correspondence is positive in February and March. Although temperature plays a secondary role in the development of tree-ring widths, its influence on available precipitation is particularly important. The connection between tree-ring data and the aridity index shows the greatest degree of negative correlation in the merged summer period (Fig. 4). It is also notable that in winter, higher aridity values play a positive role in Scots pine tree-ring width at our sites.

The moving window was employed to determine how the changes in climatic conditions over the last 100 years have affected the variability of tree-ring width on a long time-scale. Early in these 100 years, temperature had a significant effect on ring width variation in most of the examined periods, but the temporal stability of each signal proved to be weak. In parallel with the accelerating warming at the study sites, the significance of the relationship between temperature and tree-ring widths vanishes. The biggest decrease in correlation between annual increment and temperature occurred in March, but the strength of relationships also declined in July and in the winter period (Fig. 5). It is important to note that the sites were affected differently. For example, in July at the FFO site, temperature never exceeded the significance level, so the decrease in correlation had less impact. In the case of precipitation, high degree of instability was detected in the signal. Since the analysis of the individual month of July showed the highest correlation with tree growth over the whole study period, it is surprising that the strong connection that existed in the first part of the 100-year period falls below the level of significance by the end of the record. On a seasonal scale, however, the impact of precipitation persisted, thanks to the increasing trend in the correlation values of June rainfall, and even August precipitation at the SZFO site.

\section{Discussion}

In parallel with international trends (Luterbacher et al. 2004; Xoplaki 2005; Parry 2007; de Luis et al. 2014; Koprowski 2012), the climate of our study sites in Western Hungary has changed significantly over the last 100 years, which has already remarkably impacted the pine forests (Gulyás et al. 2014; Misi and Nádrádi 2016a, b), and this process will most probably continue in the future (Bozó 2010; Náfrádi et al. 2013). The climate-growth relationship observed in the tree-ring indices of our study sites is typical of areas of low elevation-moderate climate with a positive dominance of summer precipitation and a negative maximum correspondence with summer temperature. Similar behavior of such parameters had earlier been reported from Hungary in the case of other species too (e.g. Garamszegi and Kern 2014; Kern et al. 2013), and has been experienced outside of Hungary in the case of Scots pine (e.g. Michelot et al. 2012; Panayotov et al. 2013) and other conifer species (e.g. Koprowski 2012, 2013; Bijak 2010), all cases under similar climatic and environmental conditions to those at the sites. Our results indicate the amount of July precipitation is the most important limiting factor in tree-ring growth over the entire study period. In August and especially in June rainfall also correlates significantly, but with lower weight. Although the previous years' climatic conditions are usually essential for tree growth in the current investigation, only the precipitation of the previous
Table 1 Dendrochronological statistics for the two Scots pine chronologies

\begin{tabular}{llllllllll}
\hline Site name & Lenght & No. of trees & CwM & MRW (mm) & MS & SD & AC1 & MEPS & MRbar \\
\hline Fenyőfó (FFO) & $1914-2013$ & 19 & 0.651 & 2.36 & 0.234 & 1.168 & 0.785 & 0.97 & 0.44 \\
Szalafő (SZFO) & $1915-2014$ & 34 & 0.637 & 2.62 & 0.224 & 1.382 & 0.832 & 0.96 & 0.43 \\
\hline
\end{tabular}

$C w M$ Correlation with master, $M R W$ mean ring width, $M S$ mean sensitivity, $S D$ standard deviation, $A C 1$ first-order autocorrelation, MEPS mean EPS, MRbar mean Rbar 

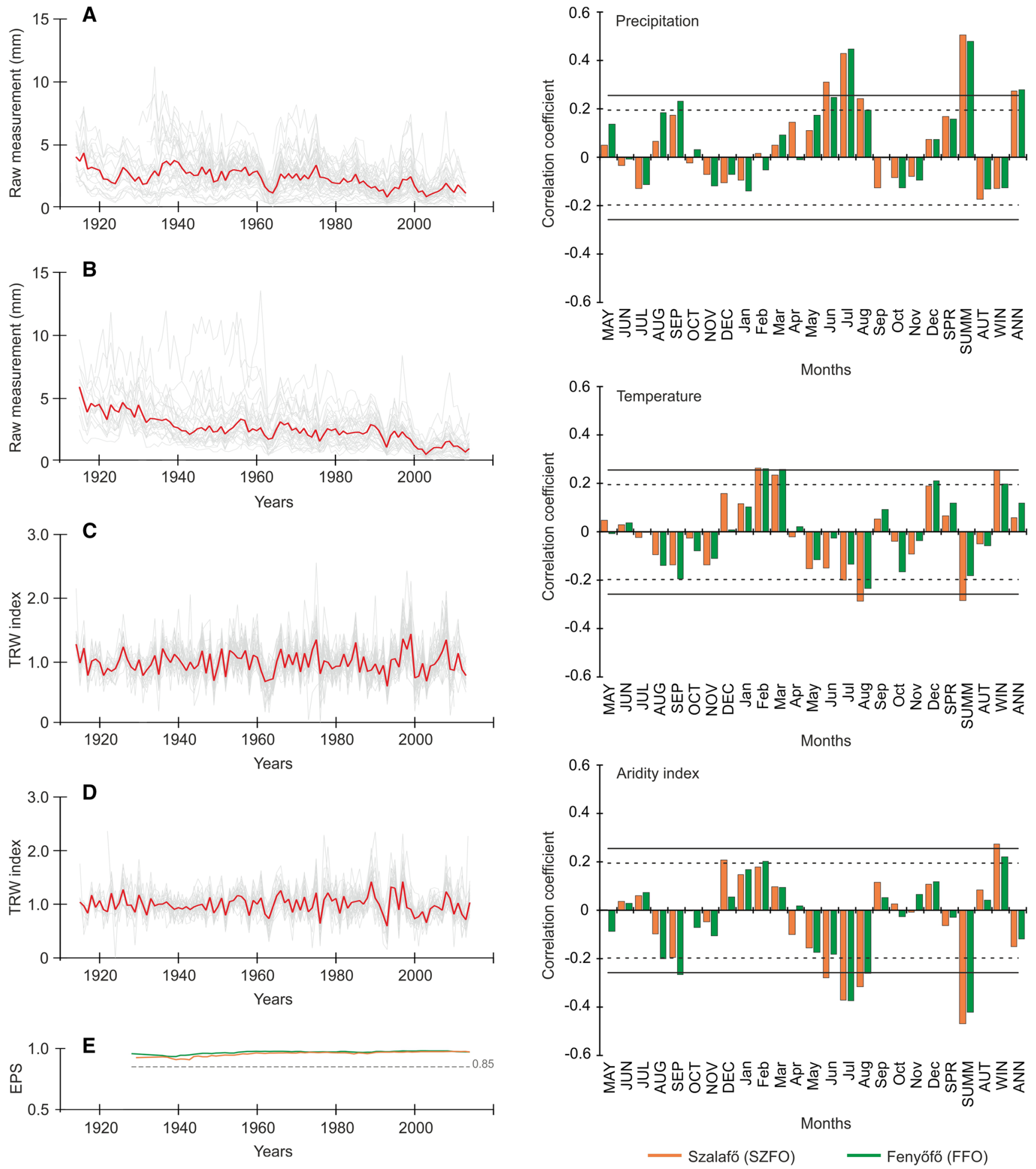

Fig. 3 Raw (a, b) and residual (c, d) chronologies of site SZFO (Szalafo) and FFO (Fenyofó). EPS values (e) indicate the stability of the climate-related signal in the tree-ring series, the horizontal dashed line marks the widely-accepted 0.85 threshold

September was significant at the FFO site. Temperature, with its negative effect on tree-ring formation, dominates in August, but its importance is lower than had been expected,

Fig. 4 Pearson correlations between precipitation, temperature, the aridity index and residual tree-ring data. The dashed $(p<0.05)$ and solid $(p<0.01)$ horizontal lines indicate the significance level

especially at the FFO site, where the role of seasonal summer temperature did not exceed the significance level $(p<0.05)$ (Fig. 4). The effect of temperature on tree growth 


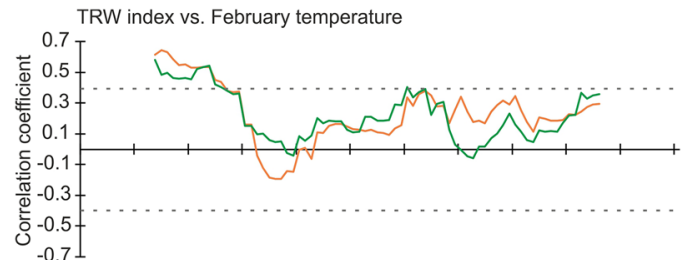

191519241933194219511960196919781987199620052014 Years

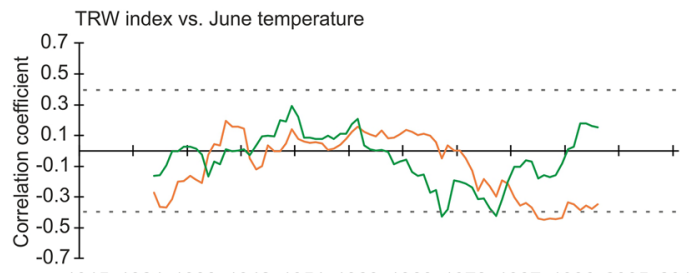

191519241933194219511960196919781987199620052014 Years

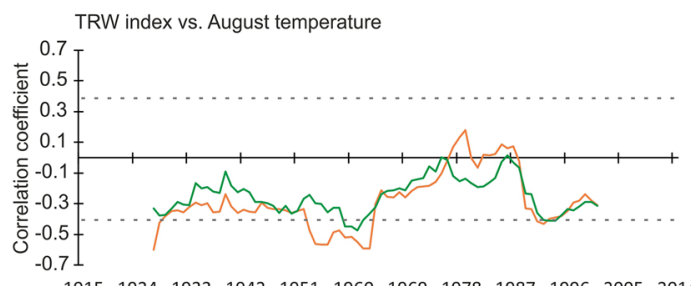

$\begin{array}{llllllllllll}1915 & 1924 & 1933 & 1942 & 1951 & 1960 & 1969 & 1978 & 1987 & 1996 & 2005 & 2014\end{array}$ Years

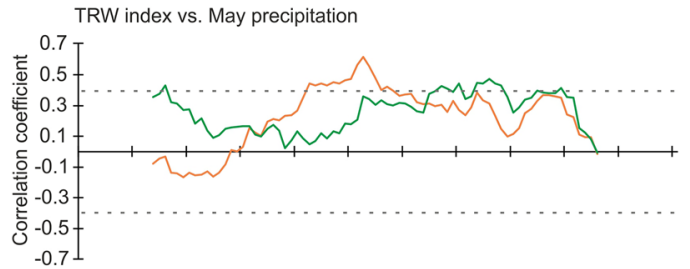

191519241933194219511960196919781987199620052014 Years

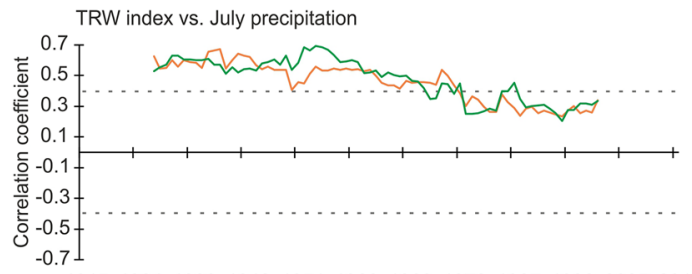

191519241933194219511960196919781987199620052014 Years

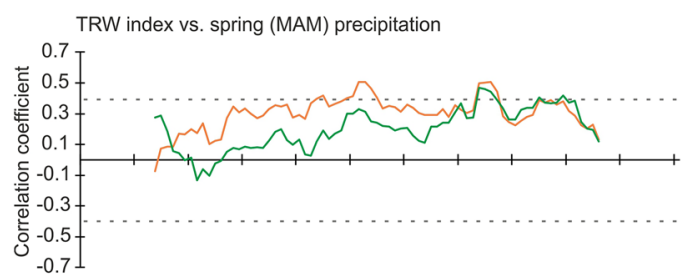

191519241933194219511960196919781987199620052014 Years

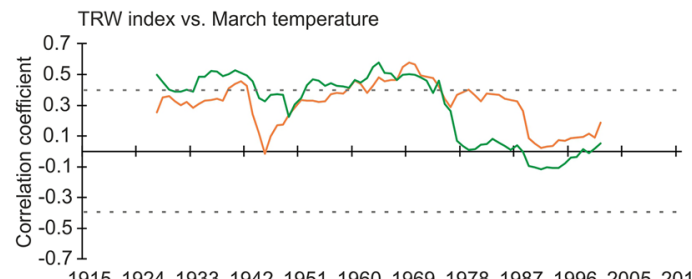

Years

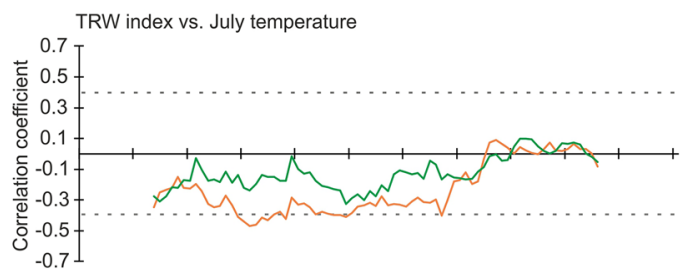

191519241933194219511960196919781987199620052014 Years

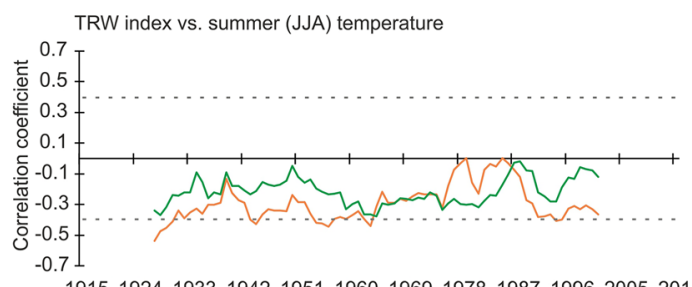

Years

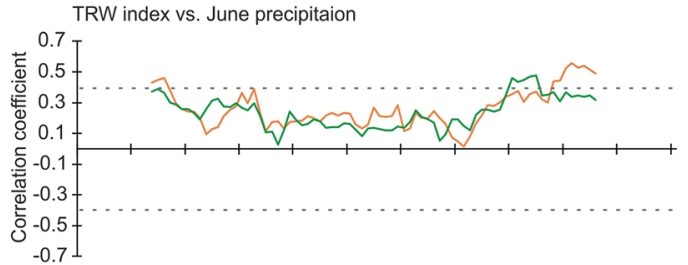

191519241933194219511960196919781987199620052014

Years

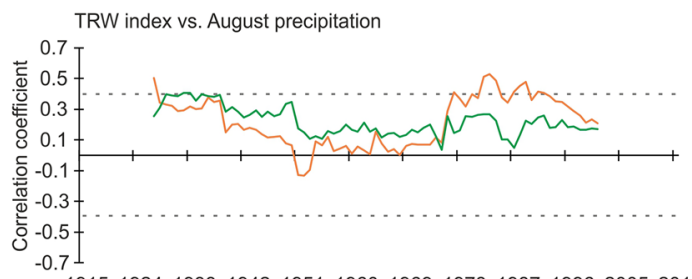

191519241933194219511960196919781987199620052014

Years

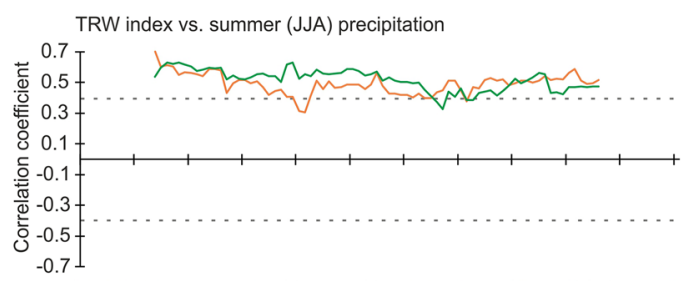

191519241933194219511960196919781987199620052014 Years

Fenyőfö (FFO)

Fig. 5 Results of the 25-year moving window correlation between tree-ring width variation and climate data in different periods of the year. Horizontal dashed lines indicate the $p<0.05$ significance level 
is highlighted to a much greater degree in the correlations with the aridity index. In this case, almost all the summer months are above the significance level (the only exception being June at the FFO site). This result shows that summer temperature has a particularly important role in tree-ring width variation, in particular due to its influence on the usable amount of precipitation. In addition to summer, a significant relationship between temperature and tree-ring widths can be found in February and March. This result is very unusual because no other papers have reported a similar pattern in Hungary (e.g. Kern et al. 2009, 2013; Garamszegi and Kern 2014). However, it is important to note that these studies were performed on beech and oak. From the region in which the country lies, some authors have observed a similar relationship for larch (Koprowski 2012, 2013), for black pine (Poljanšek et al. 2013) and for spruce trees (Bošel'a et al 2013), but generally from areas with a different climate or at a higher elevation. This positive influence in the late winter-early spring period can most probably be explained by the essential role of temperature in the onset of tree-ring formation.

The temporal stability of the climate-growth relationship of different tree species has been investigated numerous times (e.g. D'Arrigo 2008; Pärn 2009; Koprowski 2012, 2013). At our sites, it is the changing conditions of late winter-early spring and summer, which are contributing to the changing response. In spite of the increasing temperature, its role in tree-ring growth has been decreasing since the middle of the 20th century. The greatest decline has occurred in the case of February and March, when a strong positive relationship $(r>0.4)$ was observed in the first part of our study (Fig. 5). In parallel with the intensive warming, correlations in both months started to decline, and the temperature of February and March has become an insignificant factor in terms of tree-ring width variation. Koprowski $(2012,2013)$ found the same reaction to warming conditions in the late winter-early spring period in conifers in the lowland area of Poland. In those papers, he notes that because of increasing temperature not only can the correlation between tree-ring growth and temperature disappear but the warming can have a side effect that significantly alters normal tree-ring development in the form of a decreased resistance to low temperatures. This occurs as a result of higher temperatures disturbing the hardening of trees, so that they become more vulnerable to late winter-early spring frosts. A similar process has been observed at high northern latitudes as well (Briffa et al. 1998), where summer temperature is the main limiting factor of tree growth. According to tree-ring widths and density data, increasing temperature after the 1950 s caused a weakening response between conifers' tree-ring growth and mean summer temperatures (Jacoby and D'Arrigo 1995; Wilson and Luckman 2003; D'Arrigo et al. 2008). This phenomenon is called the "divergence problem". Although there are still questions concerning the exact mechanism of this phenomenon, D'Arrigo et al. (2008) have noted that temperature alone is not always sufficient to characterize the trees' thermal environment, since they will also be influenced by other factors such as soil moisture, soil temperature or insolation. At our sites we also observed a decline in the correspondence between temperature and tree-ring width variability in August and especially in July (Fig. 5). June is the only summer month, particularly at the SZFO site, whose influence on tree-ring width increased. Summer temperature was not alone in experiencing a reduced correlation. Over the first half of the last century, winter temperature had a relatively stable positive connection with our Scots pine ring width indices, but by the end of the 1990s this had completely disappeared; moreover, for a short period the relationship almost became significantly negative at the FFO site.

In general, the amount of precipitation in every month and season decreased in our moving window analysis, but this generated different correspondences with Scots pine tree ring-width variations. For example, decreasing rainfall in May, June, August, and in spring resulted in stronger correlations with tree-ring width indices, which may be a byproduct of the drastic decline in the relationship of July precipitation and tree-ring growth. Since July precipitation was the most important factor for tree-ring width development in most of the last 100 years, the weakening of its role may have enhanced the importance of other periods' precipitation conditions. The correlation of both June and August precipitation exceeded the significance level, whereas July fell beneath it (Fig. 5). Consequently, a remarkable degree of correlation decline occurred in what had been the most important month, but a stable positive correlation remained for the summer period as a whole. At the same time, the improved correlations with June and August precipitation did not affect both sites equally and to all appearances does not seem set to persist. The August correlation had dropped below the significance level by the end of the 1990s, and currently it looks like June is showing a decreasing trend as well.

The effect of changing climate on the climate-growth trends of Scots pine in our study sites is, therefore, clearly visible. Bauwe et al. (2015) note that in northern Germany the reduced growth of Scots pine tree rings will probably be moderate in the future if the positive effect of increasing winter temperatures is able to counterbalance the negative effect of summer droughts. Although that study was performed under similar climatic and environmental conditions to the current one, at our sites no increasing positive effect of winter temperature could be observed on tree-ring width development, which seems to forecast a continuing negative influence of warming and more frequently 
occurring droughts on growth dynamics and tree-ring width variation.

\section{Conclusion}

The aim of this study was to investigate climate parameters that are the main limiting factors on the tree-ring width development of Scots pine, and to evaluate the temporal stability of the climate-growth relationship in the light of climate change over the last 100 years. Our results indicate that rising temperatures and decreasing precipitation experienced in Hungary will alter tree growth drastically. The formerly dominant role of July precipitation as the most important limiting factor in tree-ring width variation has been supplanted by June and August rainfall. However, a further decline in precipitation may, in turn, change the importance of these as well. In spite of rising temperatures, the role of temperature in both the late winter-early spring period and summer has been declining. The same process has been observed in the case of conifers in Poland by Koprowski $(2012,2013)$ and also at high latitudes by numerous authors (e.g. Briffa et al. 1998; Vaganov et al. 1999; Briffa 2000; D’Arrigo et al. 2004).

Author contribution statement Dávid Misi conceived the structure and idea of the paper, carried out the main part of the sample and data collection, data analysis and writing of the paper. Katalin Náfrádi contributed to the sample collection and in the writing of the paper.

\begin{abstract}
Acknowledgements The authors would like to express their gratitude to Ms. Rita Márkus and to Mr. Szabolcs Borka for their invaluable help during sampling, and to Mr. Zoltán Kern for organizing the sample preparation and measurement. We also would like to thank the two reviewers and the editor of this paper for their valuable advice and comments.
\end{abstract}

\section{Compliance with ethical standards}

Conflict of interest The authors declare that they have no conflict of interest.

\section{References}

Bauwe A, Jurasinski G, Scharnweber T, Schröder C, Lennartz B (2015) Impact of climate change on tree-ring growth of Scots pine, common beech and pedunculate oak in northeastern Germany. iForest 9:1-11. doi:10.3832/ifor1421-008

Bauwe A, Koch M, Kallweit R, Konopatzky A, Strohbach B, Lennartz B (2013) Tree-ring growth response of Scots pine (Pinus sylvestris L.) to climate and soil water availability in the lowlands of North-Eastern Germany. Baltic For 19:212-225.
Bijak S (2010) Tree-ring chronology of silver fir and its dependence on climate of the Kaszubskie Lakeland (Northern Poland). Geochronometria 35:91-94. doi:10.2478/v10003-010-0001-9

Bogino S, Fernández MJ, Bravo F (2009) Climate effect on radial growth of Pinus sylvestris at its southern and western distribution limits. Silva Fenn 43(4):609-623.

Borhidi A (2003) Magyarország növénytársulásai. Akadémiai Kiadó, Budapest

Bozó L (2010) Környezeti jövőkép - Környezet-és klímabizottság (Ed). MTA, Budapest

Bošel'a M, Sedmák R, Sedmárková D, Marušák R, Kulla L (2013) Temporal shifts of climate-growth relationships of Norway spruce as an indicator of health decline in the Beskids, Slovakia. For Ecol Manag 325: 108-117. doi:10.1016/j. foreco.2014.03.055

Briffa K (2000) Annual climate variability in the. Holocene: interpreting the message from ancient trees Quat Sci Rev 19:87105. doi:10.1016/S0277-3791(99)00056-6

Briffa K, Schweingruber F, Jones P, Osborn T (1998) Reduced sensitivity of recent tree growth to temperature at high norther latitudes. Nature 391:65-73. doi:10.1038/35596

Churkova OV, Eugster W, Zielis S, Cherubini P, Etzold S, Saurer M, Siegwolf R, Buchmann N (2014) Increasing relevance of spring temperatures for Norway spruce trees in Davos, Switzerland, after the 1950s. Trees Struct Funct 28:183-191. doi:10.1007/s00468-013-0941-6

Cook ER, Peters K (1981) The smoothing spline: a new approach to standardizing forest interior tree-ring width series for dendroclimatic studies. Tree-Ring Bull 41: 45-53.

Cook ER (1985) A Time series analysis approach to tree-ring standardization. Dissertation, The University of Arizona, Tucson

Cook ER, Krusic PJ (2006) ARSTAN4.1b_XP. http://www.ldeo. columbia.edu.

D'Arrigo R, Wilson R, Liepert B, Cherubini P (2008) On the "Divergence Problem' in northern forests: a review of the tree-ring evidence and possible causes. Glob Planet Change 60:289-305. doi:10.1016/j.gloplacha.2007.03.004

D’Arrigo R, Kaufmann R, Davi N, Jacoby G, Laskowski C, Myneni R, Cherubini P (2004) Thresholds for warming-induced growth decline at elevational treeline in the Yukon Territory. Glob Biogeochem Cycles 18. doi:10.1029/2004GB002249

de Luis M, Čufar K, Saz MA, Longares LA, Ceglar A, KajfežBogataj L (2014) Trends in seasonal precipitation and temperature in Slovenia during 1951-2007. Reg Environ Change 14:1801-1810. doi:10.1007/s10113-012-0365-7

Eilmann B, Weber P, Rigling A, Eckstein D (2006) Growth reactions of Pinus sylvestris L. and Quercus pubescens Willd. to drought years at a xeric site in Valais, Switzerland. Dendrochronologia 23:121-132. doi:10.1016/j.dendro.2005.10.002

Garamszegi B, Kern Z (2014) Climate influence on radial growth of Fagus sylvatica growing near the edge of its distribution in Bükk Mts., Hungary. Dendrobiology 72: 89-97. doi:10.12657/ denbio.072.008

Gulyás K, Bidló A, Horváth A (2014) Causes of the Forest Die-off in a Pinus Forest (Pinus sylvestris) in Fenyőfő. In: Polgár A, Bazsó T, Nagy G, Gálos B (eds) Local and regional challenges of climate change adaptation and green technologies. Proceedings. Sopron, Hungary, pp 60-67

Harris I, Jones PD (2015) CRU TS3.23: climatic research unit (CRU) time-series (TS) version 3.23 of high resolution gridded data of month-by-month variation in climate (Jan. 1901-Dec. 2014). Centre for Environmental Data Analysis, 09 November 2015. doi:10.5285/4c7fdfa6-f176-4c58-acee-683d5e9d2ed5.

Holmes RL (1983) Computer-assisted quality control in tree-ring dating and measurements. Tree-Ring Bulletin 43:69-78 
Jacoby GC, D’Arrigo R (1995) Tree-ring width and density evidence of climatic and potential forest change in Alaska. Glob Biogeochem Cycles 9:227-234. doi:10.1029/95GB00321

Kern Z, Grynaeus A, Morgós A (2009) Reconstructed precipitation for southern Bakony Mountains (Transdanubia, Hungary) back to $1746 \mathrm{AD}$ based on ring widths of oak trees. Időjárás 113: 299-314.

Kern Z, Patkó M, Kázmér M, Fekete J, Kele S, Pályi Z (2013) Multiple tree-ring proxies (earlywood width, latewood width and $\delta^{13} \mathrm{C}$ ) from pedunculate oak (Quercus robur L.), Hungary. Quatern Int 239:257-267. doi:10.1016/j.quaint.2012.05.037

Koprowski M (2012) Long-term increase of March temperature has no negative impact on tree rings of European larch (Larix decidua) in lowland Poland. Trees Struct Funct 26:1895-1903. doi:10.1007/s00468-012-0758-8

Koprowski M (2013) Spatial distribution of introduced Norway spruce growth in lowland Poland: The influence of changing climate and extreme weather events. Quatern Int 283:139-146 doi:10.1016/j.quaint.2012.04.020

Luterbacher J, Dietrich D, Xoplaki E, Grosjean M, Wanner H (2004) European seasonal and annual temperature variability, trends, and extremes since 1500. Science 330:1499-1503. doi:10.1126/ science. 1093877

Menzel A, Fabian P (1999) Growing season extended in Europe. Nature 397:659. doi:10.1038/17709

Michelot A, Bréda N, Damesin C, Dufrene E (2012) Differing growth responses to climatic variations and soil water deficits of Fagus sylvatica, Quercus petraea and Pinus sylvestris in a temperate forest. For Ecol Manag 265: 161-171. doi:10.1016/j. foreco.2011.10.024

Misi D, Náfrádi K (2016a) Possibility of identification of negative extreme climatic events using Pinus sylvestris tree-rings in Transdanubia, Hungary. Dendrobiology 75:45-54. doi:10.12657/ denbio.075.005

Misi D, Náfrádi K (2016b) Late winter-early spring thermal conditions and their long-term effect on tree-ring growth in Hungary. Baltic For 22(2):203-211

Mérian P, Pierrat J-C, Lebourgeois F (2013) Effect of sampling effort on the regional chronology statistics and climate-growth relationships estimation. Dendrochronologia 31:58-67 doi:10.1016/j. dendro.2012.07.001

NFCSO Forestry Directorate Forest Inventory 2010-2014. http://portal.nebih.gov.hu/documents/531011/531862/2001101001000. pdf/c9a01ba7-184a-4a76-9400-59387aee2df8

Náfrádi K, Jakab G, Sümegi P, Szelepcsényi Z, Törôcsik T (2013) Future climate impacts in woodland and forest steppe based on
Holocene paleoclimatic trends, paleobotanical change in central part of the Carpathian Basin (Hungary). Am J Plant Sci 4:11871203. doi:10.4236/ajps.2013.46147

Panayotov M, Zafirov N, Cherubini P (2013) Fingerprints of extreme climate events in Pinus sylvestris tree rings from Bulgaria. Trees Struct Funct 27: 211-227. doi:10.1007/s00468-012-0789-1

Parry ML, Canziani OF, Palutikof JP, van der Linden PJ, Hanson CE (2007) IPCC, 2007: Climate Change 2007: Impacts, adaptation and Vilnerability. Contribution of Working Group II to the Fourth Assessment Report of the Intergovernmental Panel on Climate Change. Cambridge University Press, Cambridge

Poljanšek J, Ceglar A, Levanič T (2013) Long-term summer sunshine/ moisture stress reconstruction from tree-ring widths from Bosnia and Herzegovina. Clim Past 9:27-40. doi:10.5194/cp-9-27-2013

Pärn H (2009) Temporal history of relationships between Scots pine (Pinus sylvestris L.) radial growth and mean monthly temperatures. Baltic For 15:48-57.

Reich PB, Oleksyn J (2008) Climate warming will reduce growth and survival of Scots pine except in the far north. Ecol Lett 11:588 597. doi:10.1111/j.1461-0248.2008.01172.x

Rinn F (2003) TSAP-Win - time series analysis and presentation for dendrochronology and related applications. User Reference, Heidelberg

Sánchez-Salguero R, Camarero JJ, Hevia A, Madrigal-González J, Linares JC, Ballesteros-Canovas JA, Sánchez-Miranda A, Alfaro-Sánchez R, Sangüesa-Barreda G, Galván JD, Gutiérrez E, Génova M, Rigling A (2015) What drives growth of Scots pine in continental Mediterranean climates: drought, low temperatures or both? Agr Forest Meteorol 206:151-162. doi:10.1016/j. agrformet.2015.03.004

Vaganov E, Hughes M, Kirdyanov A, Schweingruber F, Silkin P (1999) Influence of snowfall and melt timing on tree growth in Subarctic Eurasia. Nature 400:149-151. doi:10.1038/22087

Wigley TML, Briffa KR, Jones PD (1984) On the average value of correlated time series, with applications in dendroclimatology and hydrometeorology. J Clim Appl Meteorol 23:201-213. doi:10.1175/1520-0450(1984)023<0201:OTAVOC > 2.0.CO;2

Wilson RJS, Luckman BH (2003) Dendroclimatic reconstruction of maximum summer temperatures from upper tree-line sites in interior British Columbia. Holocene 13:853-863. doi:10.1191/0 959683603hl663rp

Xoplaki E, Lutherbacher J, Paeth H, Dietrich D, Steiner N, Grosjean M, Wanner H (2005) European spring and autumn temperature variability and change of extremes over the last half millennium. Geophys Res Lett 32:L15713. doi:10.1029/2005GL023424 


\section{Terms and Conditions}

Springer Nature journal content, brought to you courtesy of Springer Nature Customer Service Center GmbH ("Springer Nature").

Springer Nature supports a reasonable amount of sharing of research papers by authors, subscribers and authorised users ("Users"), for smallscale personal, non-commercial use provided that all copyright, trade and service marks and other proprietary notices are maintained. By accessing, sharing, receiving or otherwise using the Springer Nature journal content you agree to these terms of use ("Terms"). For these purposes, Springer Nature considers academic use (by researchers and students) to be non-commercial.

These Terms are supplementary and will apply in addition to any applicable website terms and conditions, a relevant site licence or a personal subscription. These Terms will prevail over any conflict or ambiguity with regards to the relevant terms, a site licence or a personal subscription (to the extent of the conflict or ambiguity only). For Creative Commons-licensed articles, the terms of the Creative Commons license used will apply.

We collect and use personal data to provide access to the Springer Nature journal content. We may also use these personal data internally within ResearchGate and Springer Nature and as agreed share it, in an anonymised way, for purposes of tracking, analysis and reporting. We will not otherwise disclose your personal data outside the ResearchGate or the Springer Nature group of companies unless we have your permission as detailed in the Privacy Policy.

While Users may use the Springer Nature journal content for small scale, personal non-commercial use, it is important to note that Users may not:

1. use such content for the purpose of providing other users with access on a regular or large scale basis or as a means to circumvent access control;

2. use such content where to do so would be considered a criminal or statutory offence in any jurisdiction, or gives rise to civil liability, or is otherwise unlawful;

3. falsely or misleadingly imply or suggest endorsement, approval, sponsorship, or association unless explicitly agreed to by Springer Nature in writing;

4. use bots or other automated methods to access the content or redirect messages

5. override any security feature or exclusionary protocol; or

6. share the content in order to create substitute for Springer Nature products or services or a systematic database of Springer Nature journal content.

In line with the restriction against commercial use, Springer Nature does not permit the creation of a product or service that creates revenue, royalties, rent or income from our content or its inclusion as part of a paid for service or for other commercial gain. Springer Nature journal content cannot be used for inter-library loans and librarians may not upload Springer Nature journal content on a large scale into their, or any other, institutional repository.

These terms of use are reviewed regularly and may be amended at any time. Springer Nature is not obligated to publish any information or content on this website and may remove it or features or functionality at our sole discretion, at any time with or without notice. Springer Nature may revoke this licence to you at any time and remove access to any copies of the Springer Nature journal content which have been saved.

To the fullest extent permitted by law, Springer Nature makes no warranties, representations or guarantees to Users, either express or implied with respect to the Springer nature journal content and all parties disclaim and waive any implied warranties or warranties imposed by law, including merchantability or fitness for any particular purpose.

Please note that these rights do not automatically extend to content, data or other material published by Springer Nature that may be licensed from third parties.

If you would like to use or distribute our Springer Nature journal content to a wider audience or on a regular basis or in any other manner not expressly permitted by these Terms, please contact Springer Nature at

onlineservice@springernature.com 